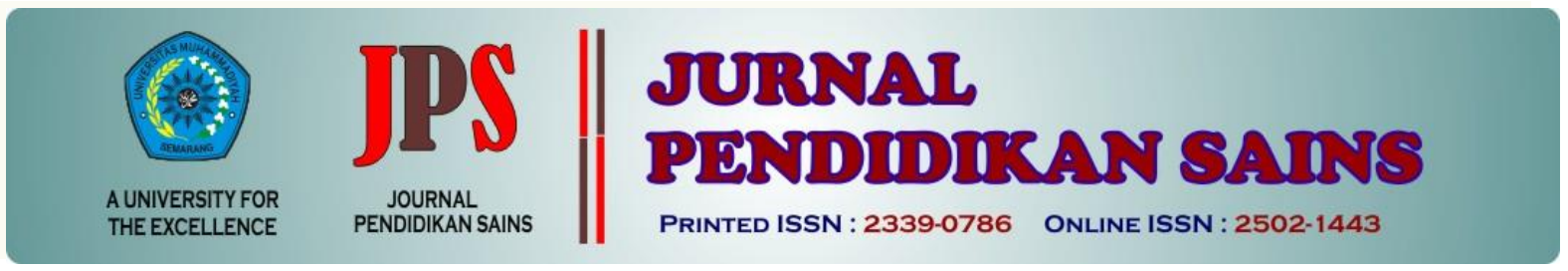

http://jurnal.unimus.ac.id/index.php/JPKIMIA

\title{
IDENTIFIKASI PEMAHAMAN KONSEP USAHA DAN ENERGI CALON GURU FISIKA
}

\author{
Oleh: \\ Lugy Rivaldo ${ }^{1}$, Muhammad Reyza Arief Taqwa ${ }^{2 *}$, Revnika Faizah ${ }^{3}$ \\ ${ }^{1}$ Pendidikan Fisika, Fakultas Keguruan dan Ilmu Pendidikan Universitas Jambi \\ lugyrivaldo@unja.ac.id \\ ${ }^{2}$ Jurusan Fisika, Fakultas Matematika dan Ilmu Pengetahuan Alam, Universitas Negeri Malang \\ reyza.arief.fmipa@um.ac.id \\ ${ }^{3}$ Pendidikan Fisika, Pascasarjana, Universitas Negeri Yogyakarta \\ revnikaf@gmail.com
}

\begin{tabular}{|c|c|}
\hline Article history & Abstract \\
\hline Submission : 2019-02-21 & This study aims to reveal the students' conceptual understanding on the \\
\hline : 2019-08-07 & concept of work and energy. In this study focused on discussing the \\
\hline : 2019-09-07 & $\begin{array}{l}\text { ability of students to understand the concept of kinetic energy. To } \\
\text { achieve this goal, } 5 \text { reasoned multiple choice questions were used. The }\end{array}$ \\
\hline $\begin{array}{l}\text { Keyword: } \quad \text { Conceptual } \\
\text { understanding, work and } \\
\text { energy, kinetic energy }\end{array}$ & $\begin{array}{l}\text { question is a standard test of basic physics lectures at UM. This } \\
\text { research is a descriptive research. The study was conducted on } 50 \\
\text { students in the "Physics Content and Its Pedagogic I" course. The } \\
\text { results showed that only } 13(26 \%) \text { students correctly answered the }\end{array}$ \\
\hline $\begin{array}{l}\text { Kata kunci: Pemahaman } \\
\text { konsep, usaha dan energi, } \\
\text { energi kinetik }\end{array}$ & $\begin{array}{l}\text { correctly answered the } K \text { ratio of the two objects driven by the same } \\
\text { force and displacement. Students' difficulties when solve the questions } \\
\text { are more likely to be caused by the habits of students using } \\
\text { mathematical equations without understanding their physical meaning, } \\
\text { in addition students also have weaknesses in mathematical operations. }\end{array}$ \\
\hline
\end{tabular}

\section{Pendahuluan}

Kemampuan pemahaman konsep merupakan salah satu kemampuan yang harus dikembangkan dalam pembelajaran sains, khusususnya pemahaman akan konsep dasar sains (Nurjamilah et al, 2017). Salah satu tujuan penting dalam pembelajaran sains seperti pembelajaran fisika adalah kemampuan pemahaman konsep fisika yang tepat sesuai dengan pemahaman fisikawan (Mustofa et al, 2016). Kemampuan memahami konsep fisika dengan tepat akan mambantu mahasiswa dalam memecahkan permasalahan dalam bidang fisika.
Energi adalah salah satu konsep dasar pembelajaran fisika yang bersifat abstrak (Jackson et al, 2007; Mustofa et al, 2016). Hampir disemua buku sains, prinsip terkait energi konservasi menyatakan bahwa energi tidak dapat di buat atau dimusnahkan (Dalaklioglu et al, 2015). Usaha dan energi merupakan salah satu konsep penting dalam pembelajaran fisika (Rahmatina et al, 2017). Mahasiswa diharapkan lebih mempelajari Energy Transfer and Transformation Proccess ketimbang definisi dari usaha dan energi (Rahmatina et al, 2017). Untuk mempelajari proses transfer dan transformasi energi,

*Corresponding Author:

Nama : Muhammad Reyza Arief Taqwa

Lembaga : Universitas Negeri Malang

Email : reyza.arief.fmipa@um.ac.id 
diperlukan pemahaman konsep usaha dan energi yang baik oleh mahasiswa.

Beberapa pendekatan untuk memperkenalkan energi dengan menunjukkan delapan konseptualisasi yang berbeda: energi adalah kuantitas akuntansi abstrak, energi adalah kemampuan untuk melakukan pekerjaan, energi adalah kemampuan untuk menyebabkan perubahan, energi adalah kemampuan untuk menghasilkan panas, energi adalah jenis umum dari bahan bakar, perbedaan konseptualis dan materialis, energi adalah kuantitas seperti zat, dan bentuk energi (Duit, 2014; Hartmann \& Priemer, 2018). Meskipun pendekatan yang berbeda ini tampak menjanjikan, banyak penelitian menunjukkan bahwa siswa berjuang untuk mengembangkan gagasan energi yang memadai (Papadouris \& Constantinou, 2016; Hartmann \& Priemer, 2018).

Dari beberapa hasil penelitian dibidang pendidikan fisika diketahui bahwa sebagian besar mahasiswa mengalami miskonsepsi terhadap materi usaha dan energi (Mustofa et al, 2016). Mahasiswa kebingungan dalam menginterpretasi kerja komponen-komponen gaya tertentu (Barniol \& Zavala, 2014). Hal ini disebabkan oleh konsep awal dan pembelajaran yang diterima mahasiswa di Sekolah (Al-idrus, 2017; Docktor \& Mestre, 2014). Oleh karena itu, penting untuk mengenali kemampuan dalam proses pembelajaran agar dapat merancang pembelajaran efektif.

\section{Metode Penelitian}

Tujuan dari dilaksanakannya penelitian ini adalah untuk mengetahui kemampuan mahasiswa pendidikan fisika dalam memahami konsep terkait materi Usaha dan Energi. Pada penelitian ini digunakan metode survei yang menggunakan instrument berupa 5 soal pilihan ganda beralasan terkait materi usaha dan energi. Soal diberikan pada 50 orang mahasiswa strata satu calon guru fisika semester 5 di Universitas Negeri Malang. Instrumen soal diberikan setelah Mahasiswa menerima materi usaha dan energi yakni pada saat Ujian Akhir Semester (UAS). Instrument soal yang diberikan diadaptasi dari buku-buku rujukan Internasional (Knight, 2017), (Serway \& Jewett, 2014), (Halliday et al, 2013) serta dari jurnal-jurnal terindeks yang disesuaikan dengan fokus penelitian.

Opsi jawaban dirancang sedemikian rupa agar mewakili konsepsi pemikiran mahasiswa, sehingga pilihan jawaban dapat menggambarkan pemikiran mahasiswa (Rivaldo et al, 2018). Yang akan difokuskan pada bagian pembahasannya adalah 2 soal pengukuran kemampuan mahasiswa dalam pemahaman konsep usaha dan energi. Kedua soal tersebut disajikan dalam representasi yang berbeda-beda, yakni gambar dalam bentuk verbal-grafik (nomor 2), gambar (nomor 4). Selain itu, kedua soal tersebut dinilai sulit karna hanya sedikit mahasiswa yang mampu menyelesaikan dengan benar.

Penelitian ini merupakan penelitian deskriptif. Fokus utama penelitan ini adalah penggambaran kemampuan mahasiswa dalam menyelesaikan soal konseptual usaha dan energi. Hal tersebut diindikasi dari keberhasilan dan kesulitan mahasiswa dalam menyelesaikan soal tersebut. Dalam penelitian ini, pembahasan difokuskan pada kemamapuan mahasiswa dalam memahami konsep energi kinetik. Kesulitan yang dialami mahasiswa akan dianalisis dengan mengumpulkan dan mengelompokam jawaban dengan alasan yang sama yang diberikan mahasiswa. Dengan menganalisis jawaban yang diberikan mahasiswa adalah untuk mengetahui kesulitan yang dialami mahasiswa dalam memahami konsep energi kinetik akibat pemahaman yang terpotong-potong (Taqwa et al, 2017) sebagaimana yang dijelaskan oleh teori knowledge in pieces (DiSessa, 2009; DiSessa \& Sherin, 1998; Hammer, 1996).

Data hasil penilaian pemahaman konsep usaha dan energi mahasiswa berupa data kuantitatif. Selain dari hasil penilaian pemahaman konsep, diperoleh juga data alasan mahasiswa dalam memberikan alasan memilih suatu opsi jawaban. Data alasan mahasiswa tersebut berupa data kualitatif sebagai pendukung data kuantitatif. Pada penelitian ini, saat proses pengambilan data analisis data tidak dilakukan, mengingat penelitian ini bertujuan untuk mengetahui kemampuan pemahaman konsep dan kesulitan yang dialami mahasiswa.

\section{Hasil Penelitian dan Pembahasan}

Jumlah dan presentase mahasiswa yang menjawab soal dengan benar ditunjukkan oleh Gambar 1. 


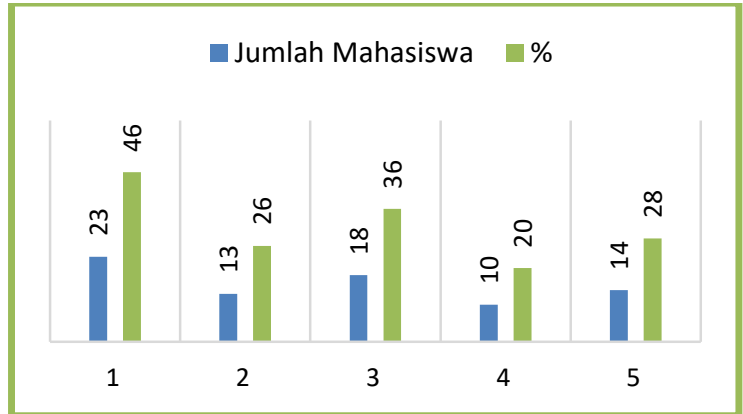

Gambar 1. Jumlah dan Persentase Mahasiswa yang Menjawab Soal dengan Benar

Dari grafik yang ditampilkan Gambar 1, dapat dilihat bahwa presentasi perolehan mahasiswa yang mampu menjawab soal dengan benar kurang dari 50\%. Rata-rata jumlaha mahasiswa yang berhasil menjawab soal tersebut dengan benar adalah sebanyak $31,2 \%$ (15,6 mahasiswa). Soal nomor 4 menjadi yang terendah presentasenya yakni hanya 20\% (10 Mahasiswa). Adapun untuk soal dengan presentase jumlah mahasiswa menjawab dengan benar yang tertinggi adalah pada nomor 1 yakni 23 mahasiswa (46\%), kemudian nomor 3 yaitu 18 mahasiswa (36\%) serta nomor 2 dan 4 hanya 26\% (13 mahasiswa) dan 28\% (14 mahasiswa).

\section{Hubungan Energi Kinetik (K) Benda terhadap Posisi $(x)$ Benda}

Pada soal ini, mahasiswa diminta untuk menentukan hubungan antara Energi Kinetik $(K)$ benda terhadap Posisi $(x)$ benda. Soal disajikan dalam bentuk representasi verbal yang ditampilkan oleh Gambar 2.

Sebuah benda bermassa $2 \mathrm{~kg}$ berada di atas lantai mendatar yang licin. Benda kemudian diberi gaya horizontal $F_{x}$ yang besarnya bervariasi terhadap $F_{x}(\mathrm{~N})$

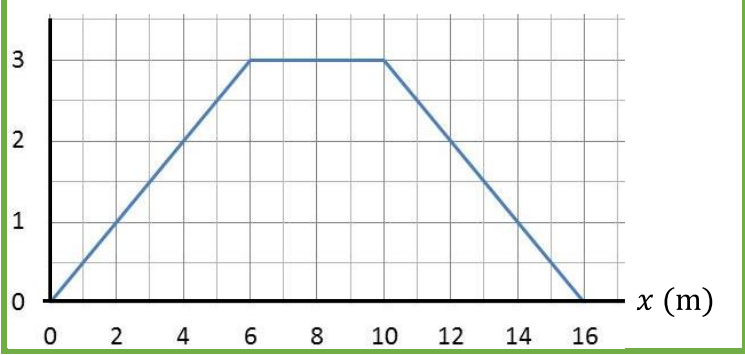

posisi seperti ditunjukkan pada grafik. Mula-mula benda diam di $x=0$.

Ketergantungan energi kinetic $(\mathrm{K})$ benda terhadap posisinya $(x)$ dalam interval $0 \leq x \leq 6 \mathrm{~m}$ adalah...
A. $\mathrm{K}(x)=1 / 4 x$
B. $\mathrm{K}(x)=1 / 2 x$
C. $\mathrm{K}(x)=1 / 4 x^{2}$
D. $\mathrm{K}(x)=1 / 2 x^{2}$
E. $\mathrm{K}(x)=x^{2}$

\section{Gambar 2. Soal Nomor 2}

Dalam menjawab soal yang ditampilkan gambar 2, hanya 26\% (13 mahasiswa) yang memilih opsi benar yaitu opsi D. Tabel 1 menginformasikan sebaran jawaban mahasiswa terkait hubungan energi kinetik $(K)$ benda terhadap posisi $(x)$ benda.

Table 1. Sebaran Pilihan Opsi Jawaban Mahasiswa dalam Menjawab Soal Nomor 2

\begin{tabular}{lll}
\hline Opsi & Pemilih Opsi \\
\cline { 2 - 3 } Jawaban & $\mathrm{N}$ & $\%$ \\
\hline A & 0 & 0 \\
B & 11 & 22 \\
C & 11 & 22 \\
D* & 13 & 26 \\
E & 9 & 18 \\
Kosong & 6 & 12 \\
\hline Total & 50 & 100 \\
\hline
\end{tabular}

Dalam menjawab soal tersebut, hanya sedikit mahasiswa yang memberikan alasan jawaban. Dalam memilih opsi E, 3 mahasiswa (dari 9 mahasiswa) memberikan alasan jawaban yang sama. Alasan jawaban yang diberikan mahasiswa ditunjukkan Gambar 3. 


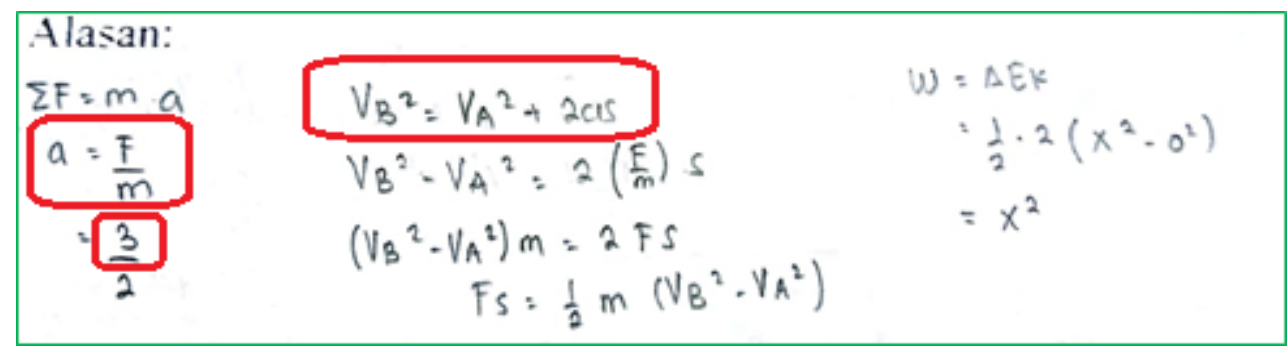

Gambar 3. Alasan Mahasiswa yang Memilih Opsi E pada Soal nomor 2

Berdasarkan alasan tersebut tampak bahwa mahasiswa menggunakan persamaan matematis tanpa memperhatikan kondisi fisisnya dengan baik. Persamaan $\sum \boldsymbol{F}=m \boldsymbol{a}$ tersebut digunakan dalam interval posisi $0 \leq x \leq$ $6 \mathrm{~m}$ dan dengan mensubstitusikan $\boldsymbol{F}=3 \mathrm{~N}$. Mahasiswa tersebut tidak memperhatikan bahwa dalam interval posisi tersebut gaya selalu berubah-ubah. Seharusnya mahasiswa menentukan terlebih dahulu fungsi $\boldsymbol{F}(x)$ sesuai grafik yang diberikan di soal. Selain itu, mahasiswa menggunakan persamaan gerak lurus dengan percepatan tetap (GLBB) yakni $v_{\mathrm{B}}^{2}=v_{\mathrm{A}}{ }^{2}+2 a s$. Artinya, mahasiswa tersebut tidak memverifikasi pengetahuannya, sehingga menggunakan persamaan GLBB pada kasus percepatan yang tidak konstan.

Sering kali mahasiswa menjawab soal dengan pendekatan plug and chug dan hanya mengingat-ingat pengetahuan yang mereka miliki (Azizah et al, 2015; Brad, 2011; Rahmat et al, 2014; Walsh et al, 2007). Berdasarkan jawaban tersebut, mengindikasikan bahwa mahasiswa mengingat tanpa memahami persamaan fisika secara parsial tanpa memaknai dengan baik. Sehingga dalam memecahkan persoalan

\section{Perbandingan Energi Kinetik antara Dua Benda}

Pada soal yang kedua ini, ditampilkan gambar ilustrasi sebagaimana yang ditunjukan oleh Gambar 4 dimana mahasiswa diminta untuk menemukan perbandingan energi kinetic antara dua benda.

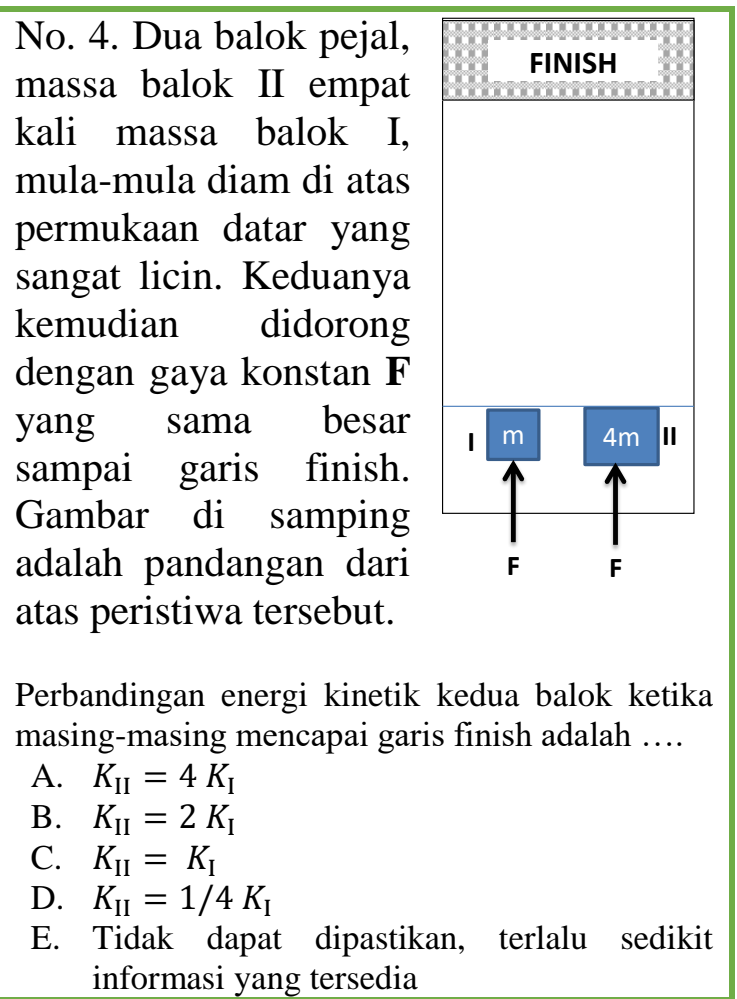

Gambar 4. Soal Nomor 4

Pilihan opsi jawaban mahasiswa dalam menemukan perbandingan energi kinetic antara dua benda di dominasi oleh pilihan opsi A. Tabel 2 menampilkan sebaran pilihan opsi jawaban mahasiswa.

Table 2. Sebaran Pilihan Opsi Jawaban Mahasiswa dalam Menjawab Soal Nomor 4

\begin{tabular}{lll}
\hline \multirow{2}{*}{ Opsi } & Pemilih Opsi \\
\cline { 2 - 3 } Jawaban & N & $\%$ \\
\hline A & 18 & 36 \\
B & 3 & 6 \\
C* & 10 & 20 \\
D & 13 & 26 \\
E & 4 & 8 \\
Kosong & 2 & 4 \\
\hline Total & 50 & 100 \\
\hline
\end{tabular}

Dalam menjawab soal nomor 4 , hanya $10(20 \%)$ mahasiswa yang mampu menjawab dengan benar. Mahasiswa lebih dominan 
memilih opsi A, yang menyatakan bahwa energi kinetik benda II adalah 4 kali energi kinetik benda I. Alasan yang diberikan oleh mahasiswa yang memilih opsi A ditunjukkan oleh Gambar 5 .

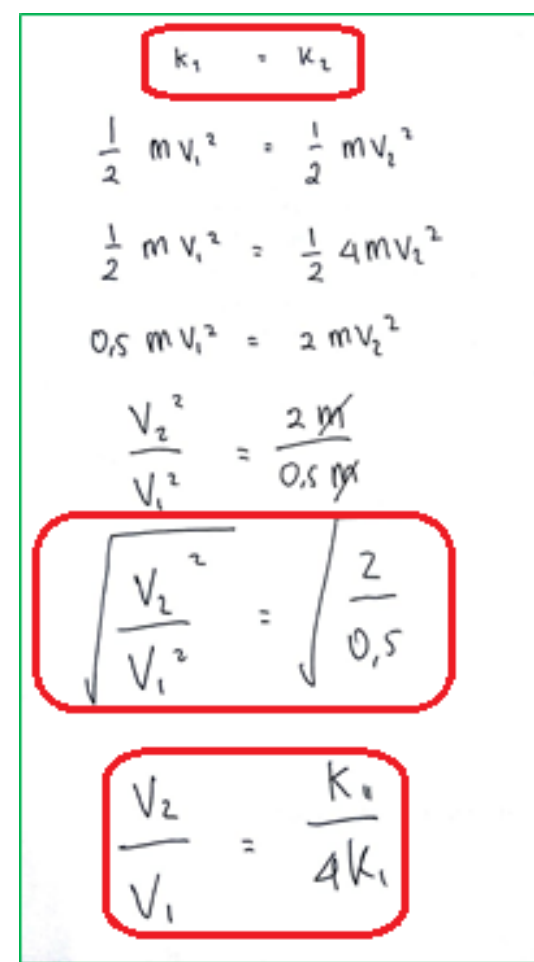

Gambar 5. Alasan Mahasiswa yang Memilih Opsi A pada Soal Nomor 4

Alasan jawaban mahasiswa seperti Gambar 5 menunjukkan bahwa mahasiswa tersebut tidak berhati-hati dalam merepresentasikan persamaan matematis. Pada awal persamaan mahasiswa menuliskan bahwa $\mathrm{K}_{\mathrm{I}}=\mathrm{K}_{\mathrm{II}}$ yang dapat disimpulkan bahwa energi kinetik kedua benda adalah sama. Namun setelah melakukan proses perhitungan diperoleh kesimpulan bahwa $\mathrm{K}_{\mathrm{II}} / 4 \mathrm{~K}_{\mathrm{I}}=v_{2} / v_{1}$, sehingga mahasiswa menyimpulkan bahwa $\mathrm{K}_{\mathrm{II}}=4 \mathrm{~K}_{\mathrm{I}}$. Alasan jawaban tersebut mengindikasikan bahwa salah satu faktor yang mengambat mahasiswa dalam memecahkan persoalan fisika adalah keterbatasan kemampuan matematik (Haryadi, 2016; Nurlailiyah, 2015; Rusilowati, 2006).

Persamaan awal yang dibangun oleh mahasiswa dalam menjawab soal tersebut merupakan persamaan yang tidak sesuai, karena sudah merupakan bentuk kesimpulan. Mahasiswa tidak memulai dari variabel yang dimunculkan dari soal. Hal tersebut menunjukkan bahwa mahasiswa belum mampu memahami soal dengan baik, sehingga tidak tepat dalam memanggil pengetahuan. Kesalahan seperti ini sering kali terjadi. Mahasiswa yang keliru dalam menjawab soal bukan berarti mahasiswa tersebut tidak memiliki pengetahuan yang benar dan relevan untuk memecahkan persoalan, hanya saja mereka gagal dakam mengaktivasi pengetahuan yang mereka miliki (Afwa, Sutopo, \& Latifah, 2016; Hammer, 2000; Taqwa et al., 2017; Taqwa \& Pilendia, 2018).

Jika kita memanggil pengetahuan mekanika Newton, yakni hukum II Newton yang menyatakan bahwa $\sum \boldsymbol{F}=\boldsymbol{m a}$, dengan percepatan yang dapat ditentukan dengan menggunakan persamaan $v_{\mathrm{t}}^{2}=v_{\mathrm{o}}^{2}+2 a s$. Karna keadaaan awal benda diam maka diperoleh bahwa $a=v_{\mathrm{t}}^{2} / 2 s$. Jika percepatan tersebut disubstitusikan dalam persamaan hukum II Newton akan diperoleh bahwa $\sum F=m v_{\mathrm{t}}^{2} / 2 s$ atau $v_{\mathrm{t}}^{2}=2 s \sum F / m$. Persamaan tersebut dapat digunakan untuk menentukan perbandingan energi kinetik kedua benda karena perpindahan, resultan gaya dan massa kedua benda diketahui. Dari persamaan energi kinetik $K=1 / 2 m v^{2}$ kita peroleh bahwa besar energi kinetik adalah $K=s$ $\sum F$. Dari persamaan tersebut dapat disimpulkan bahwa dalam kondisi perpindahan dan resultan gaya yang sama akan menghasilkan energi kinetik yang sama karena massa tidak berpengaruh.

\section{Simpulan dan Saran}

Simpulan

Mahasiswa masih mengalami kesulitan dalam menyelesaikan permasalahan usaha dan energi. Dalam menentukan ketergantungan energi kinetik terhadap posisi dari grafik $\mathrm{F}(\mathrm{x})$ hanya 26\% (13 mahasiswa) yang menjawab dengan benar. Selain itu, dalam menentukan perbandingan energi kinetik dua benda yang didorong dengan gaya konstan yang sama besar pada jarak yang sama hanya 20\% (10 mahasiswa) yang menjawab dengan benar.

Kesalahan terjadi karena keterbatasan mahasiswa dalam memaknai secara fisis suatu persamaan matematis sehingga menggunakan persamaan matematis pada konteks yang tidak relevan. Selain itu, kegagalan dalam memecahkan persoalan terjadi karena mahasiswa tidak memiliki kemampuan penyelesaian matematis yang memadai.

Saran

Penelitian ini merupakan penelitian survei yang berfokus untuk mengidentifikasi kesulitan-kesulitan yang terjadi pada 
mahasiswa. Penelitian sejenis lebih baik dilakukan untuk memperdalam data-data kesulitan umum yang terjadi. Hal ini penting untuk dapat menjadi salah satu pertimbangan dalam merancang pembelajaran yang baik. Oleh karena itu, selain penelitian yang berfokus pada rancangan pembelajaran yang efektif dalam mengajarkan topik-topik fisika, penelitian untuk mengungkap kesulitan siswa maupun mahasiswa dalam memahami dan memecahkan persoalan fisika juga masih perlu untuk terus dilakukan.

\section{Daftar Pustaka}

Afwa, I. L., Sutopo, \& Latifah, E. (2016). Deep learning question untuk meningkatkan pemahaman konsep fisika. Jurnal Pendidikan: Teori, Penelitian, Dan Pengembangan, 1(3), 434-447.

Al-idrus, S. Q. M. J. (2017). Aplikasi Android pada Pembelajaran Fisika: Sebuah Solusi Mutakhir Pembelajaran Fisika di Era Global. Prosiding Seminar Nasional Fisika Dan Aplikasinya, 214-221.

Azizah, R., Yuliati, L., \& Latifah, E. (2015). Kesulitan Pemecahan Masalah Fisika pada Siswa SMA. Jurnal Penelitian Fisika Dan Aplikasinya (JPFA), 5(2), 44-50. https://doi.org/10.26740/jpfa

Barniol, P., \& Zavala, G. (2014). Force, velocity, and work: The effects of different contexts on studentsâ $€^{\mathrm{TM}}$ understanding of vector concepts using isomorphic problems. Physical Review Special Topics - Physics Education Research, 10(2) https://doi.org/10.1103/PhysRevSTPER.1 0.020115

Brad, A. (2011). A Study of the Problem Solving Activity in High School Students: Strategies and Self-Regulated Learning. Acta Didactica Napocensia, 4(1), 21-30. Retrieved

from https://search.proquest.com/docview/1697 502999? accountid $=8144$

Dalaklioglu, S., Demirci, N., \& Sekercioglu, A. (2015). Eleventh Grade Students's Difficulties and Misconceptions About Energy and Momentum Concepts. International Journal on New Trends in Education and Their Implications, 6(1), $13-21$.

DiSessa, A. A. (2009). Toward an Epistemology of Physics. Cognition and Instruction, $10(2$ \& 3$), \quad 105-225$. https://doi.org/10.1207/s1532690xci1002

DiSessa, A. A., \& Sherin, B. L. (1998). International Journal of Science What changes in conceptual change? International Journal of Science Education, 20(10), 1155-1191. https://doi.org/10.1080/095006998020100 2

Docktor, J. L., \& Mestre, J. P. (2014). Synthesis of discipline-based education research in physics. Physical Review Special Topics Physics Education Research, 10(2), 1-58. https://doi.org/10.1103/PhysRevSTPER.1 0.020119

Hammer, D. (1996). More than misconceptions: Multiple perspectives on student knowledge and reasoning, and an appropriate role for education research. American Journal of Physics, 64(10), 1316-1325.

https://doi.org/10.1119/1.18376

Hammer, D. (2000). Student resources for learning introductory physics. American Journal of Physics, 68(S1), S52-S59. https://doi.org/10.1119/1.19520

Hartmann, B., \& Priemer, B. (2018). Introducing energy through observations and measurements. Physics Education, 7(53), $\quad 0-7 . \quad$ https://doi.org/DOI: 10.1088/1361-6552/aad615

Haryadi, R. (2016). Korelasi Antara Matematika Dasar Dengan Fisika Dasar. Jurnal Penelitian Dan Pembelajaran Matematika, 9(1), 124-127. https://doi.org/10.30870/JPPM.V9I1.988. G789

Jackson, J., Dukerich, L., \& Hestenes, D. (2007). Modeling Instruction: An Effective Model for Science Education. Spring; Science Educator, 17(1), 10-17.

Knight, R. d. (2017). Physics For Scientiest and Engineers a Strategic Approach. (J. Zalesky, Ed.) (4th ed.). USA: Pearson.

Mustofa, Z., Sutopo, \& Mufti, N. (2016). Pemahaman Konsep Siswa SMA Tentang Usaha dan Energi Mekanik. Pros. Semnas Pend. IPA Pascasarjana UM, 1, 519-528.

Nurjamilah, Nurul Fitriyah, S., \& Komariyah, L. (2017). Penggunaan Instrumen Ordered Multiple Choice (OMC) untuk Menilai Pemahaman Konsep Usaha dan Energi dengan Model Pembelajaran Discovery di SMAN 1 Long Kali. Berkala Ilmiah Pendidikan Fisika, 5(3), 241-253.

Nurlailiyah, A. (2015). Studi Korelasi antara Kemampuan Matematika dengan Hasil 
Belajar Fisika di SMA PGRI Sumberrejo Bojonegoro Tahun Ajaran 2014/2015, $5(2)$.

Papadouris, N., \& Constantinou, C. P. (2016). Investigating middle school students' ability to develop energy as a framework for analyzing simple physical phenomena. Journal of Research in Science Teaching, 53(1), 119-145. https://doi.org/10.1002/tea.21248

Rahmat, M., Muhardjito, M., \& Zulaikah, S. (2014). Kemampuan Pemecahan Masalah Melalui Strategi Pembelajaran Thinking Aloud Pair Problem Solving Siswa Kelas X SMA. Jurnal Fisika Indonesia, 18(54), 108-112. Retrieved from http://pdmmipa.ugm.ac.id/ojs/index.php/jfi/article/vi ew/898/0

Rahmatina, D. I., Sutopo, \& Wartono. (2017). Pemahaman Konsep dan Kemampuan Multirepresentasi Siswa SMA pada. Pros. Seminar Pend. IPA Pascasarjana UM, 2(1), 127-133.

Raymond A. Serway, \& John W. Jewett, J. (2014). Serway \&amp; Jewett - Physics for Scientists and Engineers with Modern Physics 9ed - Google Drive. (E. Dodd, Ed.) (9th ed.). USA: Brooks/Cole Cengage Learning.

Rivaldo, L., Taqwa, M. R. A., \& Taurusi, T. (2018). Resources Siswa SMA tentang Konsep Gaya Archimedes. Jurnal Pendidikan Fisika Universitas Muhammadiyah Makassar, 6(3), 251-258. Retrieved from http://journal.unismuh.ac.id/index.php/jpf/ issue/view/114/showToc

Rusilowati, A. (2006). Profil kesulitan belajar fisika pokok bahasan kelistrikan siswa SMA di kota Semarang. Jurnal Pendidikan Fisika Indonesia, 4(2), 100 106. Retrieved from http://journal.unnes.ac.id/nju/index.php/JP FI/article/view/163/168

Taqwa, M. R. A., Hidayat, A., \& Supoto. (2017). Konsistensi Pemahaman Konsep Kecepatan dalam Berbagai Representasi. Jurnal Riset \& Kajian Pendidikan Fisika, 4(1), 31-39. https://doi.org/http://dx.doi.org/10.12928/j rkpf.v4i1.6469

Taqwa, M. R. A., \& Pilendia, D. (2018). Kekeliruan Memahami Konsep Gaya, Apakah Pasti Miskonsepsi? Jurnal Inovasi Pendidikan Fisika Dan
Integrasinya, 01(02), 1-12.

Walker, J., Resnick, R., \& Halliday, D. (2013). Fundamentals of Physics Extended, Instructor's Solutions Manual, 1 .

Walsh, L. N., Howard, R. G., \& Bowe, B. (2007). Phenomenographic study of students' problem solving approaches in physics. Physical Review Special Topics Physics Education Research, 3(2), 1-12. https://doi.org/10.1103/PhysRevSTPER.3. 020108 